\title{
Comparison of the Hierarchies of Standards in China, USA and UK
}

\author{
Jia LI \\ China National Institute of Standardization, No. 4 Zhichun Road, Beijing, China \\ lijia@cnis.gov.cn
}

Key words: Standards system, Standards body, Standards function, Comparison.

\begin{abstract}
Nationwide standards system have been well established in developed countries such as USA and UK. Providing an introduction of their hierarchies constitution and current situation, this paper compares the standards systems in China, USA and UK in terms of standards body, scope and function, with a view of facilitating the building of new standards system and reform in standardization mechanism.
\end{abstract}

\section{Introduction}

What a standards system in a country looks like depends on its economic regime, standardization management system and strategic goals. Embedding itself in social and economic lives at all levels, a well-established standards system helps delivering strategic standardization goals, fostering market economy, safeguarding public interests, and provides technical support for laws and regulations. On the contrary, it does not work, or even hinders their development. A nationwide standards system can be classified by hierarchy, subject, type and documentation. This paper describes and compares the hierarchies of standards in China, USA and UK.

\section{The Constitutions of the Hierarchies in China, USA and UK}

\section{China's Hierarchy of Standards}

According to Standardization Law of the People's Republic of China, Chinese standards can be classified by hierarchy into national standard, industry standard, local standard, social organization standard and enterprise standard. National standards can be classified into mandatory and voluntary. Both industry and local standards are recommended ones while social organization standards are voluntary ones.

Mandatory standards are released by the State Council or with its authorization to safeguard health, life, property, state security and ecological environment and address essential needs for economic and social regulation[1]. Standardization Administration of the People's Republic of China (SAC) administers mandatory national standards by developing management regulations and systems, is responsible for proposing, informing, numbering, releasing and abolishing a national standard, steers and supervises the development and implementation of mandatory national standards. State Council Departments are designated to propose, draft, collect comments on, review and organize, supervise and evaluate the implementation of a mandatory national standards[2]. There are by far 2,089 mandatory national standards, accounting for $6 \%$ of the total national standards.

Recommended national standards are developed and administered by SAC to address needs for basic use, supporting mandatory national standards and technical requirements that guide affected industries[1], including basic standards and public standards. National technical committees (TC) are built, with the approval of SAC, to draft and review national standards. There are by far 539 TCs, 420 out of which, $77 \%$, are delegated to deal with specific activities and 119 out of which, $23 \%$, are directly responsible for specific activities. There are by far 31,726 recommended national standards, accounting for $94 \%$ of the total national standards[2].

Industry standards are developed by State Council Departments and filed with SAC. They provide technical requirements for industries where no recommended national standards were 
established but need common technical requirements, such as machinery, electronics, architecture, chemical, metallurgy, light industry, textile, transportation, energy, agriculture, forestry and water conservancy. There are by far 59,871 industry standards filed with SAC, including 67 industries[2].

Local standards are developed by authorities responsible for standard development under governments at provincial, autonomous region and municipality directly under the Central Government level. Filed with SAC, they provide technical requirements satisfying local conditions and customs[1]. There are by far 38,594 local standards filed with SAC[2].

Social organization standards are developed and published by such entities as association, society, chamber of commerce, league and industrial \& technical alliance in coordination with stakeholders. They could be used as agreed by members of an organization or are made publically available for free use [1]. They are designed to take advantage of resources in a reasonable way, put technological outcomes into practice, enhance product safety, interoperability and replace ability and increase economic, social and ecological efficiency. There are by far 3,165 standards posted at nationwide platforms on social organization standards[2].

An enterprise may develop a standard by itself or jointly with other ones according to its or their needs. A vast majority of enterprise standards are intended for production within an enterprise.

According to Standardization Law of the People's Republic of China, technical requirements provided in recommended national, industry, local, social organization and enterprise standards shall not be less strict than those in mandatory ones. Moreover, both social organization and enterprise are encouraged to develop standards respectively that provide more strict technical requirements than recommended ones.

\section{USA's Hierarchy of Standards}

USA's standards can be classified by hierarchy into national standard, society or association standard (including league standard) and enterprise standard, which constitute USA's voluntary standards system and are developed on a consensus basis and adopted voluntarily. In USA, technical regulations do not belong to the standards system, functioning like mandatory national standards in China.

USA government delegates American National Standards Institute (ANSI) to organize the development of American national standards (ANS) and release them. ANSI organizes standard development, information exchange, review and representation in international standardization activities. ANSI does not develop ANSs itself but designates ANSI-accredited standards developing organizations. By Jan. 2018, ANSI accredited 237 entities as SDO, including ASTM International, ASME, IEEE, API and UL, most of which are globally influential and part of which developed standards later adopted as factual international standard. By Jan. 2018 ANSI released 11,500 American national standards[3].

Aimed at their industries respectively, society or association standards are developed by societies (associations), interested manufacturers, users, consumers and representatives of government and academia on a consensus basis. A society (association) is a non-profit organization, which is created and represented voluntarily. They represent their members and operate on the principle of openness and transparency. They mostly engage in academic activities and industry services. Different from a society or association, a league is formed by multiple enterprises voluntarily to maximize their interests by developing standards addressing the state-of-art of their industry. In fact, this kind of standard can be regarded as reduced association standard with less scope or expanded enterprise standard[4].

In USA, technical regulations are developed and administered by government agencies. New technical regulations shall be proposed in accordance with general requirements under governing laws, to facilitate the delivery of the goals of an applicant. These requirements are mostly for healthcare, product safety, operator's/user's safety, environmental impact, quarantine, consumer protection, packaging and labelling, product properties or pubic interests. American technical regulations are aimed at safeguarding and improving citizens' health, safety, surrounding and well-being[5]. Technical regulation developing mechanism is closely related to national standard 
developing mechanism. ANSI assists government agencies in developing technical regulations while the latter designate their officers to participate in the development of national standards. To reduce the overlap, American government legislated to minimize the development of government's standards or technical regulations. The adoption of existing national standards is encouraged. When the voluntary national standards are adopted by the government's regulations, they become mandatory ones.

\section{UK's Hierarchy of Standards}

UK's standards system can be classified by hierarchy into national standard, industry association standard and enterprise standard. All these standards are voluntary. According to UK Government's Public Policies about Standardization for 2009, British standards are classified into formal and informal. The formal ones refers to standards developed by recognized standards developing organizations (BSI, ISO, CEN and CENELEC) on a consensus basis, including British national standards. The informal ones refers to standards that are developed by associations or industry communities to address market demands rapidly. Industry association standards belong to informal standards. Reference to each other and coordination between them is encouraged[6]. In UK, technical regulations do not belong to British standards system, functioning like mandatory national standards in China.

British national standards are developed in accordance with procedures for standard development under the supervision of British Standards Institution (BSI). They are aimed at safeguarding the interests of a corporation, a government and the public, fostering the competitive edge of a corporation, introducing the best practices, supporting public policies and regulations and building a framework for varying needs from all standard users. The non-profit organization BSI was accredited by UK government as national standards developing organization (NSB), having the status of UK representative of ISO, IEC, CEN and CENELEC and being tasked with putting their technical committees to work to develop national standards in accordance with procedures for standard development. There are by far 1,350 technical committees and about 10,000 members within BSI, which are representatives of standard users, manufacturers, government agencies, consumers and other stakeholders. British national standards deal with almost all areas, including engineering, manufacturing, processes and products and architecture. They are constituted by those standards developed under BSI, British national standards transformed from European standards, British national standards transformed from international standards. There are 36,987 British national standards by May 2018, 92\% of which are transformed from international or European standards [6].

Industry association standards refer to those standards developed by private organizations, e.g. Royal Institute of British Architects, The Institution of Civil Engineers, Charted Institute of Building, The Institution of Structural Engineers, The Construction Industry Council and National House Building Council. Although these standards have to be developed in accordance with specific procedures for standard development to response to market demands as soon as possible, they are usually used within their industries or league only if consensus is reached. In UK, it is encouraged to build a mechanism for transforming informal standards into formal ones, with a view of extending the application of informal standards[4].

In UK, technical regulations originate from EU's technical regulations and UK's secondary legislations, providing mandatory guidelines and requirements for national security, human health and safety, animal and plant protection and environmental protection. EU's technical regulations are developed by European Council, European Commission and European Parliament in accordance with legislative procedures, aimed at coordinating varying technical regulations and standards in members, eliminating technical trade barriers, and ensuring free movement of goods across European communities. Most of EU technical regulations come in the form of directive, including approximately 300 measures for technical coordination between different industries (Old Approach Directive) and approximately 30 new approaches to technical coordination and standards (New Approach Directive). Within EU, old Approach Directives are used for industries involving 
potential risks, such as food, chemicals, motor vehicle and pharmaceutics. New Approach Directives provide key guidelines and general requirements for safety, healthcare, environment and customer protection that apply to all affected products, instead of directly addressing specific products. Members of EU are required to convert EU directives into their national technical regulations without any conditions[7]. In most cases, secondary legislation is law that British Parliament delegate executive authorities to legislate on a certain matter. Secondary legislation is developed in accordance with Acts and with authorization. Most forms of secondary legislation are issued by Secretaries of State authorized by British Parliament and mandatory, including statutory instruments, regulations, rules and orders[8]. British technical regulations here belong to secondary legislation.

Despite being voluntary, British national standards play an important role in technical regulations. Any standards included by legislative authorities into a technical regulation, constitute part of British legal system and in turn become mandatory.

\section{Comparison of the Hierarchies of Standards in China, USA and UK}

Both American and British technical regulations do not belong to standards system. Nevertheless, they are closely related to technical standards as they usually refer to the latter and then make it mandatory. In this sense, they are similar to mandatory national standards in China. This paper therefore views them as part of standards systems in USA or UK to facilitate comparison of hierarchies of standards in the three countries. On the other hand, enterprise standards are excluded from the comparison in consideration that they are mostly used within enterprises, which suggests a small scope of application, and consensus among small group of stakeholders is reached. Comparison of the hierarchies of standards in China, USA and UK by standards body, scope and function is made as shown in Table 1.

Table1. Comparison of the Hierarchies of Standards in China, USA and UK

\begin{tabular}{|c|c|c|c|c|c|}
\hline Country & \multicolumn{2}{|c|}{ Standards System } & Standards body & Scope & Function \\
\hline \multirow{4}{*}{ China } & \multirow[t]{2}{*}{$\begin{array}{l}\text { National } \\
\text { standard }\end{array}$} & $\begin{array}{l}\text { Mandatory } \\
\text { national standard }\end{array}$ & $\begin{array}{l}\text { Developed by: } \\
\text { Responsible } \\
\text { departments under the } \\
\text { State Council (e.g. } \\
\text { Ministry of Industry } \\
\text { and Information } \\
\text { Technology) } \\
\text { Issued by: SAC }\end{array}$ & Nationwide & $\begin{array}{l}\text { Safeguard health, life, } \\
\text { property, state security and } \\
\text { ecological environment and } \\
\text { address essential needs for } \\
\text { economic and social } \\
\text { regulation. }\end{array}$ \\
\hline & & $\begin{array}{l}\text { Recommended } \\
\text { national standard }\end{array}$ & $\begin{array}{l}\text { Developed by: TC } \\
\text { Issued by: SAC }\end{array}$ & Nationwide & $\begin{array}{l}\text { Address needs for basic use, } \\
\text { supporting mandatory } \\
\text { national standards and } \\
\text { technical requirements that } \\
\text { guide affected industries. }\end{array}$ \\
\hline & \multicolumn{2}{|c|}{ Industry standard } & $\begin{array}{l}\text { Responsible } \\
\text { departments under the } \\
\text { State Council }\end{array}$ & $\begin{array}{l}\text { Within a } \\
\text { specific } \\
\text { industry }\end{array}$ & $\begin{array}{l}\text { Provide technical } \\
\text { requirements for industries } \\
\text { where no recommended } \\
\text { national standards were } \\
\text { established but need common } \\
\text { technical requirements. }\end{array}$ \\
\hline & \multicolumn{2}{|c|}{ Local standard } & $\begin{array}{l}\text { Executive } \\
\text { standardization } \\
\text { authorities under } \\
\text { governments at } \\
\text { provincial, } \\
\text { autonomous region } \\
\text { and municipality } \\
\text { directly under the } \\
\text { Central Government } \\
\text { level }\end{array}$ & $\begin{array}{l}\text { Province, } \\
\text { autonomous } \\
\text { region and } \\
\text { municipality } \\
\text { directly } \\
\text { under the } \\
\text { Central } \\
\text { Government }\end{array}$ & $\begin{array}{l}\text { Provide technical } \\
\text { requirements satisfying local } \\
\text { conditions and customs. }\end{array}$ \\
\hline
\end{tabular}




\begin{tabular}{|c|c|c|c|c|}
\hline & Standards System & Standards body & Scope & Function \\
\hline & $\begin{array}{l}\text { Social organization } \\
\text { standard }\end{array}$ & Social organization & $\begin{array}{l}\text { Used by } \\
\text { members or } \\
\text { voluntarily } \\
\text { used by the } \\
\text { public }\end{array}$ & $\begin{array}{l}\text { Take advantage of resources } \\
\text { in a reasonable way, put } \\
\text { technological outcomes into } \\
\text { practice, enhance product } \\
\text { safety, interoperability and } \\
\text { replaceability and increase } \\
\text { economic, social and } \\
\text { ecological efficiency. }\end{array}$ \\
\hline \multirow{3}{*}{ USA } & Technical regulation & $\begin{array}{l}\text { Departments } \\
\text { concerned }\end{array}$ & Nationwide & $\begin{array}{l}\text { Safeguard and improve } \\
\text { citizens' health, safety, } \\
\text { surrounding and well-being. }\end{array}$ \\
\hline & National standard & $\begin{array}{l}\text { Developed by: } \\
\text { ANSI-accredited } \\
\text { standard developing } \\
\text { organizations (SDO) } \\
\text { Issued by: ANSI, } \\
\text { which issues } \\
\text { SDO-developed } \\
\text { standards in } \\
\text { accordance with the } \\
\text { procedures }\end{array}$ & Nationwide & $\begin{array}{l}\text { Address needs for standard } \\
\text { development in key areas and } \\
\text { facilitate worldwide } \\
\text { application. }\end{array}$ \\
\hline & $\begin{array}{l}\text { Society or Association } \\
\text { standard (including league } \\
\text { standard) }\end{array}$ & $\begin{array}{l}\text { Private organizations } \\
\text { such as society, } \\
\text { association and } \\
\text { league }\end{array}$ & $\begin{array}{l}\text { Within a } \\
\text { specific } \\
\text { industry } \\
\text { (professional) } \\
\text { or a league }\end{array}$ & $\begin{array}{l}\text { Common standards are } \\
\text { necessary for an industry } \\
\text { (professional); } \\
\text { Develop standards } \\
\text { representing common } \\
\text { interests of a specific } \\
\text { industry as soon as possible; } \\
\text { Some standards have become } \\
\text { de facto international ones. }\end{array}$ \\
\hline \multirow{3}{*}{ UK } & Technical regulation & $\begin{array}{l}\text { Departments } \\
\text { concerned (which } \\
\text { transform EU's } \\
\text { Directives and } \\
\text { formulate new } \\
\text { technical regulations) }\end{array}$ & Nationwide & $\begin{array}{l}\text { Provide key guidelines and } \\
\text { general requirements for } \\
\text { safety, healthcare, } \\
\text { environment and customer } \\
\text { protection. }\end{array}$ \\
\hline & National standard & $\begin{array}{l}\text { Developed by: } \\
\text { Technical committees } \\
\text { under BSI } \\
\text { Issued by: BSI }\end{array}$ & Nationwide & $\begin{array}{l}\text { Safeguard the interests of a } \\
\text { corporation, a government } \\
\text { and the public }\end{array}$ \\
\hline & Industry association standard & $\begin{array}{l}\text { Private organizations } \\
\text { such as society, } \\
\text { association and } \\
\text { alliance }\end{array}$ & $\begin{array}{l}\text { Within a } \\
\text { specific } \\
\text { industry or a } \\
\text { organization }\end{array}$ & $\begin{array}{l}\text { Respond to market demands } \\
\text { rapidly; } \\
\text { Consensus need to be } \\
\text { reached within the industry } \\
\text { or organization. }\end{array}$ \\
\hline
\end{tabular}

\section{Analysis and Insights}

\section{Hierarchy}

Both American and British hierarchies of standards only consist of national standards and society or association standards, which are all voluntary. In both USA and UK, technical regulations do not constitute standard system but closely related to them as they are usually included into the latter and thus made mandatory. In China, government-driven standards consist of national standards (including mandatory and recommended), industry standards and local standards. Market-driven standards refer to social organization standards. In China, there are no technical regulations, but mandatory standards functioning like technical regulations, which is out of line with international practices.

Furthermore, social organization standards didn’t gain legal status in China until the end of 2017 
when Standardization Law of the People's Republic of China was issued. Despite thriving in China, they are faced with a few issues, e.g. they remain to be improved both quantitatively and qualitatively and there are no globally influential standards developing organizations in China. Social organization standards in USA and UK have been well established owing to rapid response to market demands and the state-of-art. Standards developed by a few professional associations in USA, e.g. ASTM, become de facto international standards. Therefore, we should remove institutional barriers to market-based resources deployment while maintaining socialist market economy, and make a big push to facilitate the development of market-driven social organization standards, enabling market to play a decisive role.

\section{Standards Development Bodies}

American national standards are developed by ANSI-accredited SDOs (e.g. ASTM, IEEE and ASME) and approved in accordance with governing procedures. They reflect the power of professional societies or associations and the decentralization of American standards. British national standards are developed by technical committees under BSI and approved by BSI. These committees represent almost all industries in UK, with representatives of stakeholders and of organizations of interest as members, so that they are in a position to achieve consensus among stakeholders and utilizing professional societies or associations. Chinese recommended national standards are developed by technical committees under SAC and approved by SAC. The committees' members consist of experts of stakeholders.

Although there is difference in standards body between USA and UK, they both take into account the power of professional societies or associations. Additionally, it is societies or associations that develop common standards necessary for their industries as there are not industry standards or local standards in USA or UK. How important they play a role in standardization. We should better learn from it to give a full play to social organization.

\section{Standards Function}

American national standards are designed with a view of more application in worldwide. By now there are 577 and 165 USA's P members in ISO's and IEC's technical committees respectively[3], which suggests a strong influence on the development of international standards. British national standards are aimed at safeguarding the interests of corporations, the government and the public, covering almost all industries in UK. By now 92\% of British national standards are transformed from international or European standards. Chinese national standards are designed to respond to the needs for basic use, supporting mandatory national standards and technical requirements that guide affected industries. By now 17\% of Chinese national standards adopt international standards[2].

This suggests a decisive role of USA in the development of international standards. British national standards are highly consistent with international or European standards as a result of participation in their development for UK's interests. In contrast with the two countries, China hasn't done much enough to participate in the development of international standards. We shall better deepen institutional reforms in standardization to increase the power of China over the development of international standards, and then lead the world market in standardization.

\section{Acknowledgement}

This research was financially supported by Study on Basic Theory about Standardization by Standardization Administration of the People’s Republic of China (item number: 572018B-6020).

\section{References}

[1] Standardization Law of the People's Republic of China by the 30th Session of the Standing Committee under the Twelfth National People's Congress of the People's Republic of China, Nov. 4, 2017. 
[2] Website of Standardization Administration of the People's Republic of China:

http://www.sac.gov.cn

[3] Website of ANSI: http://www.ansi.org

[4] China National Institute of Standardization, 2014 Report on International Standards Landscape. [M], Beijing: Standards Press of China, 2015.

[5] Liu Chunqing, Comparison of Similarity between Technical Regulations in USA, Europe and Japan and Lessons to China [J], Standard Science, 2010 (2): 69 - 77.

[6] Website of BSI: http://www.bsigroup.com

[7] Liu Chunqing, Liu Junhua and Yang Feng, On Standardization Mandates under New Approach: A Bridge between Legislation and Standards in Europe [J], Standard Science, 2012(6): 73-78.

[8] Zhang Yuan and Lu Jinlong, Study on British Technical Regulations and Implementation Mechanisms [J], Research \& Discussion, 2016(10): 69-75. 